\title{
EFFECT OF ERYTHROMYCIN ON INSULIN RESISTANCE AND TUMOUR NECROSIS FACTOR-ALPHA LEVELS IN FRUCTOSE FED INSULIN RESISTANT RATS
}

\author{
$\mathcal{B} Y$ \\ Amany A. M. Shalaby \\ Deparment of Clinical Pharmacology, Faculty of Mcdicine, Matsoutra University, Egypt
}

\begin{abstract}
Tumor necrosis factor-alpha (TNF- $\alpha$ ) has been suggested to play a key role in insulin resistance (IR), in obesity and may contribute to the development of type 2 diabetes mellitis. Erythronycin, one of the macrolide antibiotics was found to exert various pharmacological effects including suppression of TNF- $\alpha$ and other cytokines levels as well as antioxidant activity in various studies in human and aninats. The presen study was designed to investigate the beneficial effect of erythromycin on insulin sensitivity in rats fed high fructose diet. Albino rats of both sexes were divided into four groups containing 10 rats each. Control rats received the standard diet, while fructose fed rats received high fructose diet. Fructose and erythromycin treated rats received high fructose diet and ery/hromycin $40 \mathrm{mg} / \mathrm{kg} /$ day orally, while control ant ery/hromycin treated rats ,eceived standard diet and erythromycin. After the treatmen period of 30 days instlin resistance index, by homeostasis model assessment (HOMA) was deternined. The leveis of lipid per-oxidation. TNF- $\alpha$ and lipogran were measured. Rats feeding high fructose diet developed $a$ significan insulin resistance associated with incrensed TNF- $\alpha$, lipid per-oxidation products, TG-LDL and decrease in HDL and no change in total cholesterol level. Administration of erythromycin to high fructuse fed rats produced beneficial effect on insulin sensitivity, dyslipidemia, $T N F_{-\alpha} \alpha$ and lipid per-oxidation. A fall in $T N F$ - $\alpha$ concentration and lipid per-oxidation products by erythronycin signify the potential wility of erythronycin as an culjunct in treatment of insulin resistance.
\end{abstract}

\section{INTRODUCTION}

Feeding rats with high fructose diet affects both glucose and lipid metabolism which result in cluster of metabolic abnormalities such as glucose intolerance, hypertension, dyslipidemia and reduced insulin action (Dai et al.,1994) thus fructose- fed rats form a useful experimental model for insulin resistance.

Tumor necrosis factor-alpha (TNF- $\alpha$ ) is a peptide constitutively expressed and secreted by adipose tissue (Erosy et al., 2004). It has been demonstrated that TNF$\alpha$ may be a mediator of insulin resistance 
in obese subjects by inhibiting tyrosine kinase activity at the insulin receptor. Phosphorylation of the insulin receptor by tyrosine kinase is critical for the binding of insulin to its receptor (Hotamisligil et al., 1994).

Fructose feeding is also reported to facilitate oxidative damage and has deleterious effects both due to reduction in antioxidant defense and enhanced free radical production (Busserolles et al., 2002).

Macrolide antibiotics are active against gram-positive bacteria, Mycoplasma spp., Legionella spp., Chlamydia spp., and Haemophilus influenza (Barry et al., 1987). A part from their anti-bacterial activity, these agents exhibit a broad spectrum of pharmacological effects including antiinflammatory activity in humans and animals (Tarayre et al., 1987; Mikasa et al., 1992; Sanz et al., 2005).

Macrolides have been shown to affect several pathways of the inflammatory process, such as the migration of neutrophils. The oxidative burst in phagocytes and the production of proinflammatory cytokines such as TNF- $\alpha$ production (Takeshita et al., 1989; Hand et al., 1990; Mikasa et al., 1992; Konno et al., 1994).

Furthermore, erythromycin mimics the effect of the gastrointestinal hormone motilin by binding to its receptor and acting as motilin agonist which recently was found to stimulate insulin secretion at lower doses than that required to stimulate gastric contractile activity (Ueno et al., 2000).

This study was carried out to determine whether erythromycin could improve insulin resistance and the related abnormalities induced by high fructose feeding in rats.

\section{MATERIAL AND METHODS}

\section{Drugs:}

Erythromycin: (Eromycin tab. Julphar Co.).

\section{Animals grouping:}

Forty Albino rats of both sexes were used throughout this study. Their weight ranging from $170 \mathrm{gm}$ to 190 $\mathrm{gm}$.They were kept under the same housing condition and were divided into the following groups consisting of 10 rats each.

1) Group I: "Control group": Each rat in this group received the control diet and tap water ad libitum.

2) Group II: "High fructose fedrats":Each rat received a diet in which fructose composed $33.64 \%$ of total carbohydrate (Faure et al.,1999). 
3) Group III: Each rat received control diet and erythromycin $40 \mathrm{mg} / \mathrm{kg} /$ day orally in water (Ianaro et al., 2000).

4) Group IV: Each rat received high fructose diet and exythromycin in the same dose. The diet composition was prescribed in table (1). Data are given in grams per 100 grams of dry weight.

The animals were maintained in their respective groups for 30 days, food intake and fluid intake were measured regularly.

An oral glucose tolerance test was carried out two days before the sacrifice of the animals, for this the rats were fasted overnight and glucose $(2 \mathrm{~g} / \mathrm{kg} \mathrm{B.w})$ was given from $30 \%$ solution orally. Blood samples were collected before glucose load and, sequentially for every half an hour after glucose load up to $90 \mathrm{~min}$ and were immediately analysed for glucose. At the end of the experimental period, the rats were sacrificed by cervical decapitation, blood samples were allowed to clot and were centrifuged, serum was separated and frozen at $-70^{\circ} \mathrm{C}$ until time of the assay of the following parameters :

Serum glucose: according to the enzymatic glucose oxidase method of Trinder, (1969).

Fasting serum insulin: by enzyme linked immunosorbent assay kit, using hu- man insulin as standard.

Homeostasis model assessment (HOMA) was used as an index to measure the degree of insulin resistance and was calculated by the formula: [insulin (um/ml) glucose in mmol/l)/22.5)] (Pickavance et al., 1999).

Total serum cholesterol: Using Kits of Biomerieux Company according to Richmond (1973); HDL and LDL according to Burstein (1970) using Kits of Biomerieux Company and TG according to Fassati and Prencipe (1982) .

Serum TNF- $\alpha$ concentration was measured by TNF- $\alpha$ enzyme immune assay kit (Aderka et al., 1992).

Thiobarbituric acid reactive substance (TBARs) was determined as described earlier (Nandhini et al., 2002). In brief, the concentration of TBARs was estimated by measuring the pink- coloured chromophore upon reaction with thiobarbituric acid at $535 \mathrm{~nm}$ a standard curve was prepared using tetra methoxy propane as the standard.

\section{Statistical Analysis:}

All the values were expressed as means $\pm \mathrm{SE}$ and statistically evaluated by twoway analysis of variance considering diet and treatment as two factors. The means were tested for significance by Tukey's 
test (Zar, 1984) for multiple comparison. A value of $p<0.05$ was considered significant.

\section{RESULTS}

The level of plasma glucose, insulin and insulin resistance index of control and experimental animals are listed in table (2). The levels are significantly elevated in fructose-fed rats as compared to control rats. Erythromycin treatment to fructose fed rats prevented such increase. The degree of insulin resistance as measured by HOMA is higher in fructose fed rats while in erythromycin treated rats the values are normal.

Table (3) shows the influence of high fructose diet and erythromycin on the levels of serum TG, LDL, HDL and cholesterol. Fructose fed rats show significant ir:crease in serum TG and LDL associated with significant decrease in HDL with no change in total serum cholesterol. Exythromycin treatment shows significant decrease in serum TG and LDL associated with increase in serum HDL and no change in total serum cholesterol level.

Table (4) shows the influence of high fructose-diet and erythromycin on the levels of TBARs and serum TNF- $\alpha$. Fructose led rats show significantly higher peroxidation as compared to control rats, furthermore there is significant increase in serum TNF- $\alpha$ compared to control rats.

Erythromycin treatment significantly reduced the levels of lipid per-oxidation and TNF- $\alpha$.

The result of oral glucose tolerance test in experimental animals are depicted in (Fig I). The fasting glucose level is higher in fructose-fed rats as compared to control rats and the level is significantly lower in fructose fed rats treated with erythromycin. Significant elevations are observed in the glucose levels after the oral glucose load at all the time points in fructose fed rats. The response is similar to control in erythromycin treated rats.

\section{DISCUSSION}

In the present study high fructose-fed rats showed significant increase in serum insulin, glucose and increase in insulin resistance. Insulin resistant has been attributed to low level of insulin-stimulated glucose oxidation due to modification in the post receptor cascade of insulin action (Catena et al., 2003). High levels of dietary fructose and severe hyperglycemia may have interactive effects which contribute to the progression and development of pathology. Furthermore, high fructose feeding showed significant increase in TNF- $\alpha$ which may mediate insulin resistance by inhibiting tyrosine kinase activity at the insulin receptor (Dan Dona et al.,1998). 
Phosphorylation of the insulin receptor by tyrosine kinase is critical for the binding of insulin to its receptor (Hotamisligil et al., 1994). In addition TNF- $\alpha$ may cause insulin resistance in vivo by raising free fatty acid concentration which in turn impairs muscle glucose metabolism (Garg, 1996). High fructose feeding showed significant increase in LDL and TG associated with significant decrease in HDL and no change in total cholesterol. The increased TG level is derived from the increased production of VLDL and decrease its catabolism via decrease in lipoprotein lipase activity, also the decreased serum $\mathrm{HDL}$ may be due to decrease synthesis of HDLcholesterol from LDL-TG due to low lipoprotein lipase activity elevating fractional catabolic rate of apolipoprotein A-I (Laakso, 1993; Faure et al., 1997; Ding et al,, 2005).

Also, in the present study high fructose feeding induced increase in free radical formation "as indicated by increase in TBARs levels". Fructose feeding can induce free radical formation by down regulation of hexose monophosphate (HMP) shunt enzymes that generate reduced environment in the form of NADPH and NADH (Nandhini et al., 2005). Furthermore, an increase in catabolism of fructose would result in energy depletion in cells, making them more susceptible to peroxidation (Oda et al.,1994). Enhanced lipid per-oxidation in fructose fed rats could be associated with high circulating glucose, which enhances free radical production from glucose autoxidation and protein glycation.

Erythromycin treated rats showed significant decrease in blood glucose, serum insulin levels associated with improvement of insulin sensitivity. Erythromycin mimics the effects of gastrointestinal hormones motilin by binding to its receptor and acting as motilin agonist (Ueno et al., 2000). It was found that motilin stimulates insulin secretion and decreases blood glt. cose level at lower doses than that required to stimulate gastric contractile activity (Suzuki et al., 1998).

The improvement of insulin sensitivity by erythromycin may be attributed to its potential antioxidant effects (Miyachi et al., 1986; Labro et al., 1989) as evidenced by decrease in TBARs. In addition erythromycin decrease TNF- $\alpha$ (Iino et al., 1992; Mahgoub et al., 2005) which may explain the improvement of insulin sensitivity. The finding of Dan Dona et al. (1998) supports this result as they reported that a fall in TNF- $\alpha$ concentration may be attributed to the restoration of insulin sensitivity.

Erythromycin administration in rats produced significant decrease in TG, and LDL and increase in HDL associated with no changes in total cholesterol levels. 
These result are in agreement with others (Ueno et al. 2000) and it could be explained on the basis that erythromycin improve insulin sensitivity.

On the light of this study it could be concluded that erythromycin treatment has a beneficial effect in the reversal of insulin resistant and might prove useful in the treatment of non-hyperglycemic insulin resistance states such as obesity and impaired glucose tolerance as well as in the treatment of established non insulin dependant diabetes mellitus. 
Shalaby, A. A. M.

Table (1): Diet composition of standard and high fructose diet $(\mathrm{gm} / 100 \mathrm{gm}$ of dry weight)

\begin{tabular}{|c|c|c|}
\hline & Standard diet & High fructose diet \\
\hline \hline Glucose & 38 & 15.56 \\
\hline Fructose & - & 33.64 \\
\hline Wheat starch & 20 & 8.40 \\
\hline Casein & 23 & 23 \\
\hline Cellulose & 6 & 6 \\
\hline Corn oil & 5 & 5 \\
\hline Salt mixture & 7 & 7 \\
\hline Vitamins & 1 & 1 \\
\hline
\end{tabular}

Table (2): Levels of serum glucose, insulin, insulin sensitivity index of control and experimental animals.

\begin{tabular}{|c|c|c|c|c|}
\hline Parameters & CON & FRU & $\begin{array}{c}\text { FRU + } \\
\text { Erythromycin }\end{array}$ & $\begin{array}{c}\text { CON }+ \\
\text { Erythromycin }\end{array}$ \\
\hline Glucose (mg/dl) & $81.22 \pm 7.79$ & $97.35 \pm 2.37^{\mathrm{a}^{*}}$ & $87.52 \pm 6.22^{\mathrm{b}^{\circ}}$ & $84.99 \pm 6.62$ \\
\hline Insulin (u U/ml) & $54.21 \pm 4.03$ & $90.70 \pm 4.00^{\mathrm{a}^{*}}$ & $59.63 \pm 5.49^{\mathrm{b}}$ & $57.40 \pm 8.04$ \\
\hline $\begin{array}{c}\text { Insulin resistance } \\
\text { index (HOMA) }\end{array}$ & $12.52 \pm 1.24$ & $21.59 \pm 1.08^{\mathrm{a}^{*}}$ & $13.56 \pm 0.67^{\mathrm{b}^{*}}$ & $12.7 \pm 1.56$ \\
\hline
\end{tabular}

Values are means $\pm \mathrm{SE}$ from 10 animals in each group. a- compared with $\mathrm{CON}$.

b- compared with FRU. $\quad(\mathrm{P}<0.05)$.

HOMA $=\frac{\text { Insulin }(\mathrm{u} \mathrm{U} / \mathrm{L}) \times \text { glucose }(\mathrm{m} \mathrm{mol} / \mathrm{L})}{22.5}$ 
Table (3): Levels of serum cholesterol, HDL, LDL and TG of control and experimental animals.

\begin{tabular}{||c|c|c|c|c|}
\hline Parameters & CON & FRU & $\begin{array}{c}\text { FRU + } \\
\text { Erythromycin }\end{array}$ & $\begin{array}{c}\text { CON + } \\
\text { Erythromycin }\end{array}$ \\
\hline \hline $\begin{array}{c}\text { 1- Cholesterol } \\
(\mathrm{mg} / \mathrm{d} l)\end{array}$ & $80.5 \pm 0.8$ & $81.2 \pm 0.9^{\mathrm{a}}$ & $79.9 \pm 0.9^{\mathrm{bS}}$ & $80.5 \pm 0.7$ \\
\hline 2- HDL (mg/dl) & $49.3 \pm 0.4$ & $25 \pm 0.3^{\mathrm{a}^{*}}$ & $46.9 \pm 0.7^{\mathrm{b}^{*}}$ & $47.9 \pm 0.6$ \\
\hline 3- LDL (mg/d) & $37.8 \pm 0.8$ & $50.7 \pm 0.9^{\mathrm{a}^{*}}$ & $35.9 \pm 0.7^{\mathrm{b}^{*}}$ & $36.9 \pm 0.5$ \\
\hline 4- TG (mg/d) & $94.6 \pm 0.7$ & $135.2 \pm 1^{\mathrm{a}^{*}}$ & $96.9 \pm 0.6^{\mathrm{b}^{*}}$ & $94.5 \pm 0.8$ \\
\hline
\end{tabular}

Values are mean $\pm S E$. a- compared with $C O N$ b-compared with FRU.

NS $=$ Non - significant. $(P<0.05)$

Table (4): Levels of serum TBARs and TNF- $\alpha$ in control and experimental animals.

\begin{tabular}{|c|c|c|c|c|}
\hline Parameters & CON & FRU & $\begin{array}{c}\text { FRU + } \\
\text { Erythromycin }\end{array}$ & $\begin{array}{c}\text { CON + } \\
\text { Erythromycin }\end{array}$ \\
\hline $\begin{array}{c}\text { 1- TBARs } \\
(\mathrm{n} \mathrm{moles/ml})\end{array}$ & $1.64 \pm 0.04$ & $2.15 \pm 0.10^{\mathrm{a}^{*}}$ & $1.66 \pm 0.09^{\mathrm{b}^{*}}$ & $1.66 \pm 0.04$ \\
\hline $\begin{array}{c}2-\mathrm{TNF}-\alpha \\
(\mathrm{pg} / \mathrm{ml})\end{array}$ & $0.91 \pm 0.1$ & $3.84 \pm 0.25^{\mathrm{a}^{*}}$ & $0.98 \pm 0.3^{\mathrm{b}^{*}}$ & $0.95 \pm 0.23$ \\
\hline
\end{tabular}

Values are mean $\pm S E$. a- compared with control b- compared with FRU $(P<0.05)$ 
Shalaby, A. A. M.

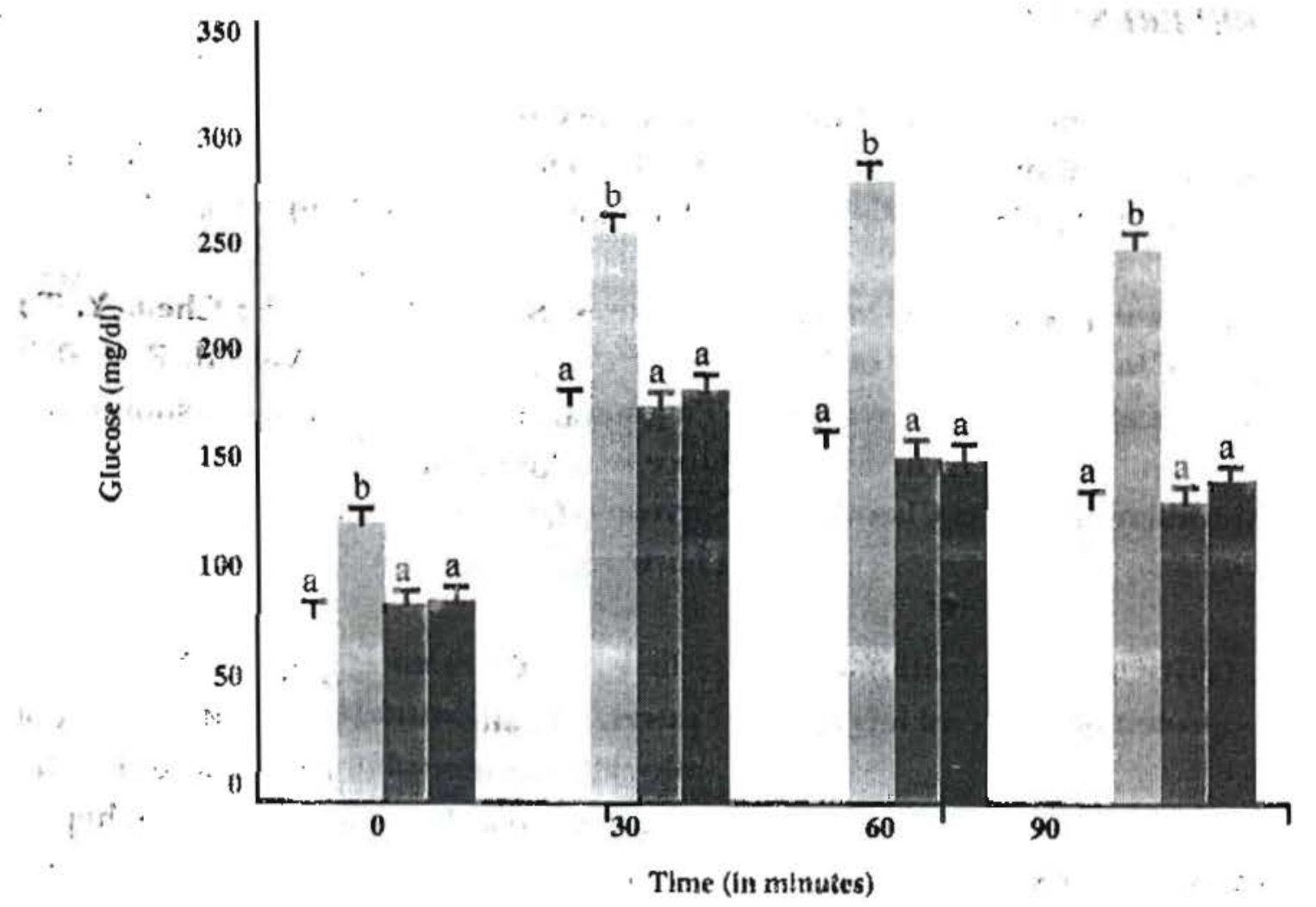

$\because \mathrm{CON}$

FRU

FRU + Erythromycin

CON + Erythromycin

- Fig. (1): Oral glucose tolerance test. 


\section{REFERENCES}

Aderka, K.; Engelmann, C, and Maor, M. (1992) : "Measurethent of the bioactivity of TNF-a". J. Exp. Med., 175: 323-329.

Batry, A. L.; Thornsberry, C. and Jones, R. N. (1987) : "In vitro activity of a new thacrolide A-56268, compared with that of roxithromycin, erythromycin and clindamycin". Antimicrob. Agents Chemother., 31: 343-345.

Burstēin, M. (1970) : "Determination of high density lipoprotein cholesterol level". Lipid Res.;11:583.

Busserolles, J.; Gueux, Ev; Rock, Et Mazur, A. and Rayssiguier, Y. (2002) : "Substituting honey for refined carbohydrates protects rats from hypertriglyceridemic and pro-oxidative effects of fructose". J. Nutr., 11: 3379-82.

Catena, C.; Giachetti, G.; Novello, M.; Colussi, G.; Cararape, A. and Sechi, L. A. (2003) : "Cellular mechanísms of insulin resistance in rats with fructose induced hypertension". Am. J. Hypertens., 16: 9738.

Ddi, S; Todd, M. E; Lee, S. and MC Neill, J. H. (1994) : "Fructose loading induces cardiovascular metabolic changes in non-diabetic and diabetic rats". Can. I. Physiol. Pharmacol., 72: 771-81.
Dan Dona, P.; Weinstock, R.; Thusu, H. and Abdel-Rahman, E. (1998) : "Tumour necrosis factor in sera of obese patients : fall with weight loss". J. Clin. Endocrinol. Metab., 583 (6) : 2907 - 2910.

Ding, S. V;; Shen, Z. F.; Chen, Y. T.; Sun, S. J.; Liu, Q. and Xie, M. Z. (2005): "Pioglitazone can ameliorate insulin resistance in low dose streptozotocin and high sucrose-fat diet induced obese rats". Acta. Pharmacol. Sin., 26 (5): 575-80.

Ersoy, C.; Imamoglu, S.; Budak, F.; Tuncel, E. and Erturk, E. (2004) : "Effect of amlodipine on insulin resistance and tumour necrosis factor alpha levels in hypertensive obese type 2 diabetic patients". Indian J. Med. Res., 120: 481-488.

Fassati, M. and Prencipe, L. (1982) : "Enzymatic determination of Triglycerides". Clin. Chem., 28: 2077.

Faure, P.; Rossini, E.; Lafond, J. L; Ríchard, M. J.; Favier, A and Halimi, S. (1997) ! "Vitamin E improves the free radical defense system potential and insulin sensitivity of rats fed-high-fructose diets". J. Nutr.; 123: 103-107.

Faüre, $P_{i} ;$ Rossini, E; Wiensperger, $\mathbb{N}$, and Favier,A. (1999):"An insulin sensitizer improves the free radical defense system potential and insulin sensitivity in high fructose fed rats". Diabetes,48:353-357. 
Garg, A. (1996) : "Insulin resistance in the pathogenesis of dyslipidema". Diabetes Care, 19: 387-389.

Hand, W. L.; Hand, D. L. and KingThompson, N. L. (1990) : "Antibiotic inhibition of the respiratory burst response in human polymorphnuclear leukocytes". Antimicrob. Agents Chem., 34:863-870.

Hotamisligil, G. S.; Budavari, A.; Murray, D. and Spiegelman, B. M. (1994) : "Reduced tyrosine kinase activity of the insulin receptor in obesity-diabetes central role of tumour necrosis factor-a". Clin. Invest., 94: 1543-1549.

Ianaro, A.; lalenti, A.; Maffia, P.; Sautebin, L. and Iuvone, T. (2000) : "Antiinflammatory activity of macrolide antibiotics". The J. of Pharmacol. \& Experiment. Therap., 292: 156-163.

Iino, Y.; Toriyama, I.; Kudo, K.; Natori, Y. and You, A. (1992) : "Erythromycin inhibition of lipopoly saccharide-stimulated tumour necrosis factor alpha production by human monocytes in vitro". Ann. Otol. Rhinol. Laryngeal. Suppl., 157: 16-20.

Konno, S.; Asano, K.; Kurokawa, M.; Ikeda, K.; Okamoto, K. and Adachi, M. (1994) : "Antiasthmatic activity of macrolide antibiotic, roxithromycin: analysis of possible mechanisms in vitro and in vivo". Int. Arch. Allergy Inumunol., 105: 308-316.
Laakso, M. (1993) : "The possible pathophysiology of insulin resistance syndrome". Cardiovasc. Risk Factors, 3:55-66.

Labro, M. T.; El Benna, J. and Babin Chevaye, C. (1989): "Comparison of the in vitro effect of several macrolides on the oxidative burst of human neutrophils". J. Antimicrob. Chemother., 24: 561-572.

Mahgoub, A.; El Medany, A.; Mustafa, A.; Arafah, M. and Moursi, M. (2005): "Azithromycin and erythromycin ameliorate the extent of colonic damage induced by acetic acid in rats". Toxicol. Appl. Pharmacol., 15: 43-52.

Mikasa, K.; Kita, E.; Sawak, M.; Rashiba, S. and Narita, N. (1992) : "The antiinflammatory effect of erythromycin in zymosan-induced peritonitis of mice". J. Antimicrob. Chemother., 30: 339-348.

Miyachi, Y.; Yoshioka, A ; Imamura, S. and Niwa, Y. (1986) : "Effect of antibiotics on the generation of reactive oxygen species". J. Invest. Dermatol., 86 : 449-453.

Nandhini, A. T.; Balakrishnan, S. D.; and Anuradha, C. V. (2002) : "Response of liver antioxidant system to taurine in rats fed high fructose diet". Int. J. Exp. Biol., 40: 1016-1019.

Nandhini, A. T. A.; Thirunarukkarasu, V.; Ravichandran, M. K. and Anuradha, 
C. V. (2005) : "Effect of taurine on biomarkers of oxidative stress in tissues of fructose-fed insulin resistant rats". Singapore Med. J., 46 (2): 82-87.

Oda, A.; Bannai, C.; Yamoka, T.; Katori, T. and Yamashitak, F. (1994) : "Inactivation of $\mathrm{Cu}-\mathrm{Zn}$. SOD by in vitro glycosylation in erythrocytes of diabetic patients". Horm. Metab. Res., 26: 1-4.

Oung, R. A.; Gonzalez, J. P. and Sorkin, E. M. (1989) : "Roxithromycin : A review of its antibacterial activity, pharmacokinetic properties and clinical efficacy". Drugs, 37: 8-41.

Pickavance, L. C.; Tadayyon, M.; Widdowson, P. S.; Buckingham, R. E. and Wilding, J. P. (1999) : "Therapeutic index of rosiglitazone in dietary obese rats. Separation of efficacy and haemodilution". Br. J. Pharmacol., 128: 1570-6.

Richmond, W. (1973) : "Enzymatic determination of cholesterol". Clin. Chem., 19: 1350-1356.

Sanz, M. J.; Nabah, Y. N.; CerdaNicolas, M. and Morcillo, E. J. (2005) : "Erythromycin exerts in vivo antiinflammatory activity down regulating cell adhesion molecule expression". Br.J. Pharmacol., 155(2): 190-201.
Suzuki, H.; Mochiki, E.; Haga, N.; Satoh, M. and Itoh, Z. (1998) : "Motilin controls cystic release of insulin through vagal cholinergic muscarinic pathways in fasted dogs". Am. J. Physiol., $279 \mathrm{G}: 87-95$.

Takeshita, K.; Yamagishi, I.; Harada, M.; Otomo, S. and Mizushima, Y. (1989) : "Immunological and anti-inflammatory effects of clarithromycin: Inhibition of interleukin-I production of murine peritoneal macrophages". Drugs Exp. Clin. Res., XV: 527-533.

Tarayre, J. P.; Aliaga, M.; Barbara, M. and Couzinier, J. P. (1987) : "Cutaneously applied erythromycin base reduces various types of inflammatory reactions in mouse ear". Int. J. Tiss. Reac., IX: 77-85.

Trinder, P. (1969) : "Enzymatic determination of glucose". Ann. Clin. Biochem., 6: 24-29.

Ueno, N.; Inui, A.; Takao, F.; Tani, S.; I-Toh, Z. and Kasuga, M. (2000) : "Erythromycin improves glycamic control in patients with type II diabetes mellitus". Diabetologia, 43: 411-415.

Zar, G. H. (1984) : Biostatistical Analysis. 2nd ed., Prentice-Hall, Inc., New jersey. 


\section{تأثبر الإريثرو مـايسين على مقاو عة هغعول الأنسولين و هيعا هل نذر الورم ألفا في الجرذان التهى تغذت بسكر الغركتوز}

ב. أهـانس عبدالرحهرن هشمد شلبك

$$
\text { تسمى الفارماكولوجى الإكلينيكى - طب المنصورن }
$$

أجرى هذا البحث لدراسة التأثبر الإيجابى للإريثررمايسين على حساسبة الأنسولين فى الجرذان البيضا ، رالتى غذيت على كمبة كبيرة من سكر الفركتوز وذلل لإحداث مقاومة لمععول الأنسولين.

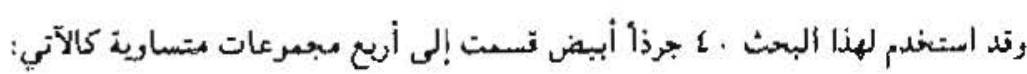

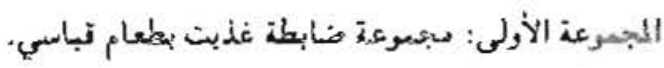

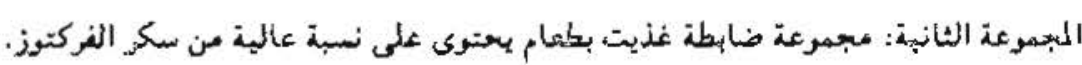

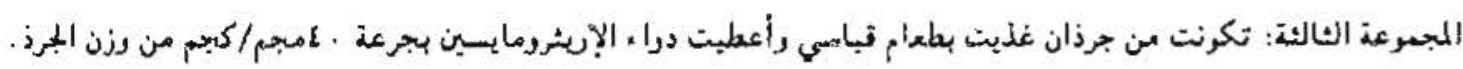

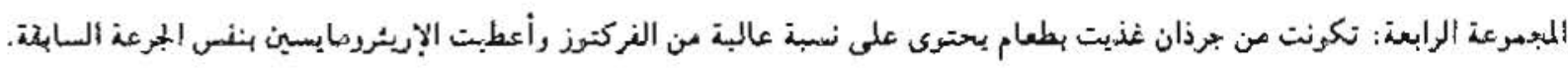

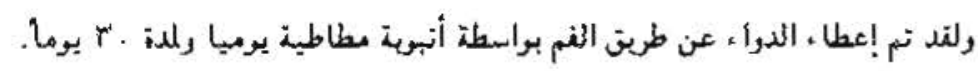

$$
\begin{aligned}
& \text { ץ- كتاس نسبة الأسمولين في الدم. } \\
& \text { أ- تباس مستوى الشقرن الحرة. }
\end{aligned}
$$$$
\text { وتم تقيبم نتانج البيتث بواسطة المعايير الآتية: }
$$

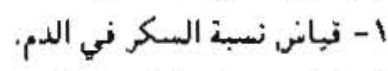

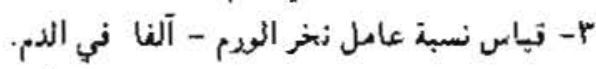$$
\text { ه- مباس نسبة الدهون الثلائية رالكوليستبرول. }
$$$$
\text { ريكن ثلغيبص نتأتج البحث كالآتي: }
$$

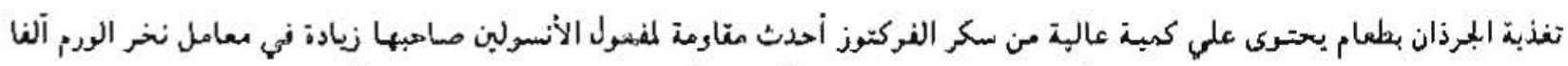

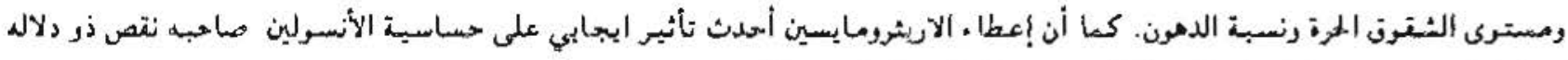

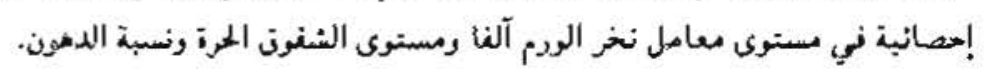

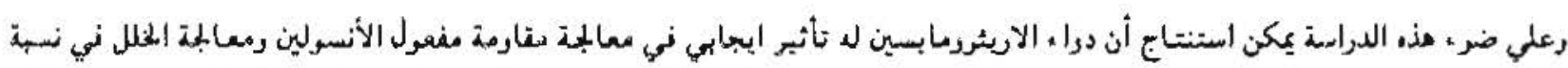

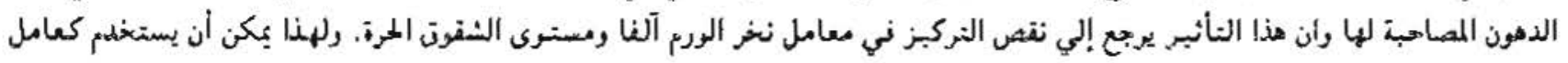

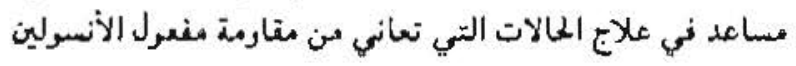


